\title{
Dylematy prawa ubezpieczeń obowiązkowych a kodeks ubezpieczeń
}

\section{Wprowadzenie}

Regulacja prawna ubezpieczeń obowiązkowych jest de lege lata rozproszona i wysoce niespójna. Wynika to m.in. $z$ faktu, że jest to materia leżąca na pograniczu prawa cywilnego oraz publicznego (administracyjnego, finansowego), do której należy wprowadzenie i reglamentacja tzw. przymusu ubezpieczenia oraz jego egzekwowanie. To sprawia, że przyjęcie zasady jednolitości ${ }^{1}$ stosunku ubezpieczenia (dobrowolnego i obowiązkowego) nie rozwiązuje wszystkich problemów związanych $\mathrm{z}$ prawnym uregulowaniem materii tych ubezpieczeń. Wydaje się bowiem oczywiste, że poza uregulowaniem cywilnej problematyki (co już samo w sobie powoduje trudności $\mathrm{w}$ zestawieniu $\mathrm{z}$ ubezpieczeniami dobrowolnymi) należy zastanowić się nad legislacyjnym usytuowaniem i uporządkowaniem także problematyki publicznoprawnej w odniesieniu do reglamentacji i funkcjonowania przymusu ubezpieczenia.

Propozycja opracowania, a następnie wdrożenia kodeksu ubezpieczeń (gospodarczych) ${ }^{2}$ stanowi dobrą okazję do rozważenia zasadniczych dylematów wiążących się z potrzebą legislacyjnego porządkowania całości materii ubezpieczeń obowiązkowych.

1 Zob. W. Warkałło, Ubezpieczenia a kodyfikacja prawa cywilnego, Wiadomości Ubezpieczeniowe 1960, nr 3, s. 3-24.

2 Zob. O potrzebie kodeksu ubezpieczeń, red. E. Kowalewski, Toruń 2009. 


\section{Jednolitość stosunku ubezpieczenia jako koncepcyjny punkt wyjścia}

Jeszcze kilkadziesiąt lat temu - w szczególności w czasie obowiązywania ustawy z $1958 \mathrm{r}^{3}{ }^{3}$ - w literaturze ubezpieczeniowej rozważany był problem natury prawnej stosunku ubezpieczenia obowiązkowego ${ }^{4}$. Ponieważ był to stosunek powstający ex lege, a ponadto jego treść była regulowana przepisami wykonawczymi ${ }^{5}$, których materia miała charakter unormowań przeważająco administracyjnych, ówczesna literatura skłonna była upatrywać w nim stosunek typu publicznego ${ }^{6}$. Czyniono nawet analogie ze zobowiązaniami podatkowymi, a składkę $z$ tytułu ubezpieczenia obowiązkowego (ustawowego) nazywano quasi-podatkiem ${ }^{7}$. Nie bez znaczenia było również to, że składka podlegała egzekucji administracyjnej, a roszczenia $z$ tego tytułu przedawniały się na tych samych zasadach i w tych samych terminach jak zobowiązania podatkowe. Swoistą pożywką dla głoszenia podobnych poglądów był wspomniany już dualizm reżimów prawnych, obowiązujących w zakresie ubezpieczeń umownych (dobrowolnych) oraz w materii ubezpieczeń obowiązkowych (ustawowych). Stosunki ubezpieczeń dobrowolnych podlegały regulacji kodeksu cywilnego oraz kodeksu morskiego, w obrębie zaś ubezpieczeń obowiązkowych, wobec ich szczegółowej reglamentacji w aktach wykonawczych, przepisy wspomnianych kodeksów nie miały zastosowania.

Ostatecznie jednak - i to już w latach obowiązywania wspomnianej ustawy z 1958 r. - zwyciężyła teza o jednolitym, cywilnoprawnym charakterze stosunku ubezpieczenia dobrowolnego i obowiązko-

3 Ustawa o ubezpieczeniach majątkowych i osobowych $z$ dn. 2.12.1958 r. (Dz.U. Nr 72, poz. 357 ze zm.).

4 Szeroko na ten temat W. Warkałło, Prawo ubezpieczeniowe, Waszawa 1983, s. 66 i n.

5 Były to rozporządzenia RM, a później - pod rządem ustawy o działalności ubezpieczeniowej z 1990 r. - rozporządzenia ministra finansów.

6 Por. W. Warkałło, op.cit., s. 168-169.

7 Por. w tej kwestii J. Łazowski, Wstęp do nauki o ubezpieczeniach, Warszawa 1948. 
wego. To z kolei - jak pisze W. Warkałło ${ }^{8}$ - przesądziło o dopuszczalności odpowiedniego stosowania kodeksowych przepisów o umowie ubezpieczenia do stosunków ubezpieczenia obowiązkowego, o ile przepisy regulujące te ubezpieczenia nie stanowiły odmiennie. Powyższe zapatrywanie - podzielane także przez orzecznictwo sądowe ${ }^{9}$ - nie wyeliminowało jednak samo przez się formalnego dualizmu regulacji prawnych. Stan ten utrzymywał się jeszcze przez kilkadziesiąt lat, aż do wejścia w życie obecnie obowiązującej ustawy o ubezpieczeniach obowiązkowych z 22 maja 2003 r., która przyjęła zasadę wyłącznie kontraktowej formuły ubezpieczenia gospodarczego ${ }^{10}$. Wprowadziła ona wprawdzie ramową regulację stosunku ubezpieczenia obowiązkowego ${ }^{11}$, przesądziła jednak $\mathrm{w}$ art. 22, że we wszystkich kwestiach w tej ustawie nieregulowanych stosuje się przepisy k.c. o umowie ubezpieczenia (oraz inne). Należy też zaakcentować, że chodzi nie o stosowanie od p ow i e d n i e, lecz wprost ${ }^{12}$.

Niestety, stan prawny wprowadzony w omawianej materii przez wspomnianą ustawę z 2003 r. nie doprowadził do wyeliminowania dualizmu regulacyjnego w zakresie ubezpieczeń umownych i obowiązkowych, przynajmniej od strony formalnej. Ściślej, chodzi o to, że nadal mamy do czynienia $z$ separatystycznym prawem umowy ubezpieczenia obowiązkowego, zawartym w ustawie o ubezpieczeniach obowiązkowych. Regulacja ta nie tylko dubluje rozliczne kwestie ujęte w k.c. (w przepisach o umowie ubezpieczenia), ale nadto regulacje te często odbiegają od uregulowań kodeksowych. W tym stanie rzeczy zasada odesłania do kodeksu cywilnego, zawarta w art. 22 ustawy, jest rozwiązaniem niedoskonałym, albowiem niektóre przepisy kodeksowe po prostu - niejako ze swej

\footnotetext{
8 Por. W. Warkałło, op.cit.

9 Szeroko na ten temat T. Ereciński, Sąowe dochodzenie roszczeń z tytułu obowiazkowych ubezpieczeń komunikacyjnych, Warszawa 1976, s. $13-31$.

10 Por. E. Kowalewski, Prawo ubezpieczeń gospodarczych, wyd. III, Bydgoszcz-Toruń 2006, s. 277.

11 Szerzej E. Kowalewski, T. Sangowski, Prawo ubezpieczeń gospodarczych. Komentarz, Warszawa 2004, s. 246.

12 Ibidem.
} 
natury - nie nadają się do stosowania w obrębie ubezpieczeń obowiązkowych, na co słusznie zwraca uwagę wielu autorów ${ }^{13}$.

Powyższy problem związany $z$ owym dualizmem reżimów prawnych musi zostać właściwie rozwiązany w przyszłym kodeksie ubezpieczeń, jeśli ma to być regulacja całokształtu stosunków ubezpieczenia i jeśli zasada jedności prawnego stosunku ubezpieczenia dobrowolnego i obowiązkowego ma zostać utrzymana i ugruntowana. Wydaje się, iż właściwym rozwiązaniem byłoby zamieszczenie w tym kodeksie - po przepisach ogólnych o umowie ubezpieczenia - przepisów szczególnych o umowie ubezpieczenia obowiązkowego. Regulacja ta stanowiłaby wówczas lex specialis w stosunku do części ogólnej umowy ubezpieczenia, co - z techniczno-legislacyjnego punktu widzenia - eliminowałoby potrzebę utrzymywania obecnej regulacji cywilnych stosunków ubezpieczenia w odrębnej ustawie. Ponadto zasada odesłania do ogólnych przepisów o umowie obowiązkowego ubezpieczenia nie budziłaby wątpliwości takich jak do tej pory ${ }^{14}$.

\section{Potrzeba redefinicji pojęcia ubezpieczenia obowiązkowego}

Jeśli zgodzić się z tym, że przyszły kodeks ubezpieczeń ma swym zakresem objąć materię ubezpieczeń obowiązkowych (zwłaszcza ich cywilnoprawną regulację) ${ }^{15}$, a jednocześnie uporządkować całościowo obszar regulacji tych ubezpieczeń, to musi on przede wszystkim precyzyjnie $z$ d e f i n i o w a ć pojęcie ubezpieczenia obowiązkowego, a ściślej - dokonać swoistej jego redefinicji. Obecne ujęcia zawarte w przepisach ustawy o ubezpieczeniach obowiązkowych jak słusznie stwierdza W. Mogilski ${ }^{16}$ - zadania tego nie spełniają, co więcej - są zbyt ogólnikowe i niejednoznaczne. Podstawowy

13 Szerzej W. Mogilski, Zagadnienia legislacyjne ubezpieczeń obowiąkowych w Kodeksie ubezpieczeń, [w:] O potrzebie Kodeksu ubezpieczeń, red. E. Kowalewski, Toruń 2009, s. 184 i n.

14 Por. W. Mogilski, op.cit., s. 184.

15 Tak słusznie W. Mogilski, op.cit., s. 169.

16 Ibidem, s. 176. 
zarzut polega na tym, że wspomniana ustawa zdaje się stawiać znak równości pomiędzy ubezpieczeniem obowiązkowym a ustawowym przymusem (zawarcia) umowy ubezpieczenia, co de iure nie jest tym samym. Doprowadziło to do swoistej inflacji obowiązkowych ubezpieczeń, których faktycznej liczby prawie nikt nie jest w stanie zliczyć $^{17}$, a lista ta jest nieustannie zwiększana, przybierając rozmiar klęski legislacyjnej ${ }^{18}$.

Jednym $z$ podstawowych dylematów, $z$ jakim przyjdzie się uporać przy opracowywaniu kodeksu ubezpieczeń, będzie zatem wprowadzenie precyzyjnego pojęcia ubezpieczenia obowiązkowego, podstawy prawnej jego wprowadzenia oraz kryteriów prawnych pozwalających rozróżnić ubezpieczenia obowiązkowe sensu stricto od wielu przypadków, w których prawo przewiduje jedynie obowiązek posiadania przez określony podmiot ochrony ubezpieczeniowej, a więc tzw. powinności ubezpieczenia. Tak rozumiana powinność zawarcia ubezpieczenia nie powinna sama przez się przesądzać o kwalifikowaniu danego ubezpieczenia jako obowiązkowego w rozumieniu ustawy (kodeksu).

Jeśli dokonamy takiej redefinicji, to okaże się, że wiele rodzajów ubezpieczeń obowiązkowych w rzeczywistości nimi nie będzie, co $z$ kolei rozwiąże inne kwestie, np. w zakresie stosowania odpowiednich przepisów prawnych.

Reasumując ten wątek rozważań, należy w pełni podzielić poglądy W. Mogilskiego, że pojęcie ubezpieczenia obowiązkowego należy zarezerwować tylko do takich przypadków, w których ustawodawca precyzuje nie tylko sam przymus zawarcia umowy, ale określa także jego zakres (podmiotowy i przedmiotowy), wskazując procedurę egzekwowania przymusu, ustalając jednocześnie podmioty (organy) do tego uprawnione oraz przewiduje konsekwencje (sankcje) naruszenia obowiązku. Przy takim założeniu nie powinno być miejsca na regulację warunków poszczególnych ubezpieczeń obowiązkowych w aktach prawnych wykonawczych, które często stają się namiastką ogólnych warunków ubezpieczenia.

17 Por. E. Kowalewski, Prawo ubezpieczeń gospodarczych, s. 86-95 i $283-284$.

18 Por. W. Mogilski, op.cit., s. 177. 


\section{Ubezpieczenia obowiązkowe w architekturze kodeksu ubezpieczeń}

Jeśli myślimy o kodeksie ubezpieczeń jako o kompleksowej regulacji stosunków ubezpieczeniowych (zarówno cywilno-, jak i publicznoprawnych), to wydaje się oczywiste, że powinien on objąć swym zakresem także - jak to już podkreślono - materię ubezpieczeń obowiązkowych. Wkomponowanie jej w ramy kodeksu nie będzie jednak łatwe już choćby $z$ tego względu, że jest ona de lege lata niezwykle rozproszona i chaotyczna. $Z$ jednej bowiem strony obowiązuje ustawa o ubezpieczeniach obowiązkowych z 2003 r. oraz wielość ustaw tzw. merytorycznych, wprowadzających poszczególne rodzaje ubezpieczeń obowiązkowych, czyli takie ubezpieczenia, które nie mają swojej szczegółowej regulacji w ustawie o ubezpieczeniach obowiązkowych (np. ustawa prawo lotnicze, ustawa o adwokaturze, doradcach podatkowych i wiele innych). $Z$ drugiej strony obowiązuje pokaźna lista aktów wykonawczych do tychże ustaw $^{19}$, określających minimalny zakres danego ubezpieczenia (sumy gwarancyjne) oraz jego podstawowe parametry dotyczące tzw. podstawowego zakresu podmiotowego oraz przedmiotowego jak również czasokresu wymaganej ochrony.

O ile można się zgodzić, że problematyka cywilnoprawna ubezpieczeń obowiązkowych ${ }^{20}$ powinna być umiejscowiona w kodeksie w sąsiedztwie ogólnej regulacji umowy ubezpieczenia, o tyle można mieć wątpliwości, czy regulacje szczegółowe, mające w przeważającej mierze charakter administracyjnoprawny (włącznie $z$ określeniem szczegółowych procedur egzekwowania i kontroli spełnienia obowiązku ubezpieczenia w zakresie poszczególnych rodzajów ubezpieczeń), powinny również znaleźć się w tym kodeksie. Zadanie to, przynajmniej od strony techniczno-legislacyjnej, wydaje się wręcz niemożliwe do realizacji, a przynajmniej wysoce utrudnione.

19 Są to $z$ reguły rozporządzenia ministra finansów; co do ich listy por. E. Kowalewski, Prawo ubezpieczeń gospodarczych, s. 89 i n.

20 Chodzi tu o szczególne uregulowania cywilnoprawne stosunków z umów ubezpieczeniowych, zawarte obecnie w roz. 1 ustawy o ubezpieczeniach obowiązkowych (art. 1-22). 
Jakie więc rozwiązanie należałoby zaproponować?

Wydaje się, że możliwe do przyjęcia byłoby rozwiązanie polegające na doprecyzowaniu zakresu oraz przedmiotu ochrony w treści ustawy (konwencji) wprowadzającej obowiązek danego ubezpieczenia, włącznie $z$ minimalnymi sumami gwarancyjnymi. Należałoby jednocześnie określić prawne konsekwencje naruszenia obowiązku (np. utrata określonego zezwolenia czy zakaz prowadzenia działalności). Natomiast szczegółowe warunki samej umowy powinny określać poszczególne zakłady ubezpieczeń, wydając odpowiednie OWU, a więc na podobnych zasadach, np. w wypadku ubezpieczeń dobrowolnych. Przy takim rozwiązaniu wydawanie rozporządzeń wykonawczych do ustaw wprowadzających dane ubezpieczenie obowiązkowe byłoby zbędne. Zostałaby w ten sposób rozwiązana sprawa patologii legislacyjnej, polegająca na określaniu swoistych warunków poszczególnych ubezpieczeń obowiązkowych przez organy resortowe (głównie Ministra Finansów), jak to jest obecnie ${ }^{21}$.

\section{Katalog ubezpieczeń obowiązkowych}

Prace nad kodeksem ubezpieczeń, jeśli ma im przyświecać idea porządkowania i racjonalizacji regulacji prawnoubezpieczeniowych, winny doprowadzić do gruntownego zweryfikowania i ograniczenia zakresu obowiązkowej ochrony ubezpieczeniowej. Lista ubezpieczeń obowiązkowych, jeśli rozumieć będziemy pod tym pojęciem wszystkie ubezpieczenia $z$ elementem przymusu zawarcia umowy, jest obecnie nadmiernie rozbudowana i to nie tylko co do ich liczby ${ }^{22}$, ale także co do rodzajów i przypadków owej obowiązkowości. Wywo-

21 Wydaje się, że podobny pogląd wyraził również W. Mogilski, op.cit., s. $176 \mathrm{i} \mathrm{n}$.

22 Co do owej listy por. E. Kowalewski, Prawo ubezpieczeń gospodarczych, s. 88-90 i 275-284 oraz M. Krajewski, Umowa ubezpieczenia. Art. 805-834 k.c. Komentarz, Warszawa 2004, s. 29-32. Od czasu wydania cytowanych pozycji liczba tych ubezpieczeń znacznie wzrosła. 
łuje to zdecydowany sprzeciw nauki prawa ubezpieczeniowego ${ }^{23}$. choć - co trzeba przyznać - nie jest on już tak silny w środowisku ubezpieczeniowym (zakładów ubezpieczeń) czy wśród niektórych adresatów owego obowiązku (np. rolników). Proces owej swoistej inflacji obowiązkowości wydaje się nie mieć końca, co w porównaniu z innymi krajami europejskimi (może poza Francją) ${ }^{24}$ jest nieco zdumiewające i niepokojące. Ubezpieczenia w formie obowiązkowej powinny być wprowadzane wyłącznie wtedy, gdy przemawiają za tym ważkie względy społeczne czy gospodarcze, wśród których potrzeba szczególnej ochrony poszkodowanych (np. w wypadkach komunikacyjnych), narażonych na intensywne ryzyko szkód masowych czy też katastrofalnych (np. przy pokojowym wykorzystaniu energii jądrowej) powinna być głównym motywem branym pod uwage przez ustawodawcę. Wprowadzenie obowiązkowych form ubezpieczenia poza tymi niezbędnymi przypadkami doprowadzić może do podważenia istoty rynkowej formuły ubezpieczenia jako instytucji cywilnoprawnej, nie mówiąc już o tym, że ogranicza to zasadę swobody kontraktowej w zakresie tych stosunków. Niezależnie od tego, że przymus taki zakłóca ekonomiczne stymulatory popytu na usługi ubezpieczeniowe, ma on bez wątpienia negatywny wpływ także na tzw. świadomość ubezpieczeniową społeczeństwa, które traci nawyk dbania o swoje interesy ekonomiczne, oglądając się na nakazowo-rozdzielcze dyspozycje państwa.

Szczególną krytykę wywołuje - i to już od wielu lat ${ }^{25}$ - sprawa obowiązkowości ubezpieczenia budynków rolniczych, a także - choć

23 Por. J. Łopuski, Reforma cywilnego prawa ubezpieczeniowego: uwagi na marginesie proponowanych zmian przepisów kodeksu cywilnego dotyczacych umowy ubezpieczenia, [w:] Umowa ubezpieczenia. Dyskusja nad forma prawna i treścią unormowań, red. A. Nowak, D. Fuchs, S. Nowak, wyd. II, Warszawa 2007, s. 67-68.

24 Gdzie wprowadzono prawie 200 rodzajów takich ubezpieczeń, głównie odnoszących się do poszczególnych zawodów i form działalności gospodarczej.

25 Por. A. Wąsiewicz, Węzłowe problemy ubezpieczeń gospodarczych wynikające $z$ nowych warunków i zasad funkcjonowania gospodarki narodowej, Studia Ubezpieczeniowe, Warszawa-Poznań 1989, t. XI, s. 15. 
w mniejszym stopniu - ubezpieczenia OC rolników. Kwestiom tym poświęcimy nieco więcej uwagi w dalszej części artykułu.

\section{Zakres przedmiotowy ubezpieczeń obowiązkowych}

Zdecydowana większość wprowadzonych do tej pory rodzajów ubezpieczeń obowiązkowych to ubezpieczenia odpowiedzialności cywilnej (OC). Rozciąganie tej obowiązkowości na inne rodzaje ubezpieczeń majątkowych czy osobowych ma charakter wyjątkowy. Przykładami owych innych ubezpieczeń obowiązkowych są: ubezpieczenie budynków rolniczych, towarów w domach składowych, upraw rolnych czy ubezpieczenie NW sportowców ${ }^{26}$. Można mieć poważne wątpliwości, czy wprowadzanie tak licznych rodzajów i form ubezpieczeń obowiązkowych znajduje racjonalne uzasadnienie, wszak potrzeba wzmożonej ochrony interesu poszkodowanych (tzn. interesu o wymiarze bez wątpienia ogólnospołecznym) - poza ubezpieczeniem OC - nie występuje, a niekiedy taki obowiązek może mieć charakter niekonstytucyjny ${ }^{27}$.

W tym miejscu należy zwrócić uwagę na to, że verba legis obowiązek ubezpieczenia może dotyczyć - poza ubezpieczeniami OC tylko ubezpieczeń mienia ${ }^{28}$. Jest to dodatkowy argument przemawiający za pilną potrzebą redefinicji w przyszłym kodeksie pojęcia ubezpieczenia obowiązkowego. Jestem zdecydowanym zwolennikiem ograniczenia ubezpieczeń obowiązkowych wyłącznie do poszczególnych (niezbędnych) przypadków ubezpieczeń OC. Wymuszanie na podmiotach właścicielskich obowiązku ubezpieczenia ich mienia bez istnienia wyraźnej potrzeby ochrony osób trzecich (a więc interesu ogólnego) nie może znaleźć usprawiedliwienia w warunkach demokratycznego państwa prawa, deklarującego liberalizm

26 Por. w tej kwestii B. Wojno, Koncepcja ubezpieczenia obowiazkowego $w$ prawie polskim, Wiadomości Ubezpieczeniowe 2005, nr 9-10, s. 36 i n.

27 Dotyczy to w szczególności ubezpieczenia budynków rolniczych.

28

Por. art. 3 ust. 1 ustawy o ubezpieczeniach obowiązkowych z 2003 r. 
gospodarczy i zasadę swobody kontraktowej jako swoiste fundamenty aktywności ekonomicznej obywateli ${ }^{29}$. Szczególną krytykę wywołują quasi-obowiązkowe ubezpieczenia upraw w rolnictwie, połączone $z$ przywilejem uzyskania znaczących dotacji na cele płaconej przez rolnika składki, i to dotacji ze środków publicznych (unijnych) ${ }^{30}$.

Swoistym kuriozum jest na tym tle obowiązek ubezpieczenia NW sportowców, który jest powszechnie ignorowany, ponieważ ustawodawca zapomniał wprowadzić odpowiednie procedury egzekwowania tego obowiązku oraz sankcje za jego naruszenie. Jeśli idzie natomiast o ratyfikowane przez Polskę konwencje międzynarodowe, to nie widzę wśród nich żadnej, która wprowadzałaby obowiązek ubezpieczenia poza ubezpieczeniem $\mathrm{OC}^{31}$.

\section{Niekonstytucyjność obowiązkowego ubezpieczenia budynków rolniczych}

Przymusowe ubezpieczenie budynków od ognia ma w Polsce ponad 200-letnią tradycję ${ }^{32}$, a jego początki bywają wręcz uważane za początek ubezpieczeń gospodarczych na obszarze ziem polskich $^{33}$. Należy przypomnieć, że u progu XIX stulecia, kiedy odpo-

29 Por. w tej kwestii L. Morawski, Zasady wykładni prawa, Toruń 200 s. 116.

30 Szerzej por. J. Łopuski, op.cit., s. 66-68.

31 Co do wykazu tych konwencji por. E. Kowalewski, Prawo ubezpieczeń gospodarczych, s. 94-95.

32 Przymus takiego ubezpieczenia, jeśli idzie o ziemie byłego zaboru pruskiego, został wprowadzony już w 1803 r. (budynki na terenie miast), a w 1804 r. w odniesieniu do budynków na terenie wsi. Por. szerzej T. Sangowski, [w:] 185 lat ubezpieczeń gospodarczych $w$ Polsce, praca zbiorowa, Warszawa 1988, s. 127-134.

33 Jest to pogląd niesłuszny i świadczący o powszechnej niemal niewiedzy na temat bogatych tradycji ubezpieczeniowych w naszym kraju, sięgających przełomu wieku XV i XVI. Szerzej E. Kowalewski, W sprawie dwusetnej rocznicy ubezpieczeń gospodarczych, PUR 2003, nr 5, s. 30. Por. też E. Kowalewski, Prawo ubezpieczeń gospodarczych. Ewolucja i kierunki przemian, Bydgoszcz 1992, s. 44-45. 
wiednimi aktami prawnymi taki przymus wprowadzono ${ }^{34}$, był on uzasadniony szczególną potrzebą ochrony budowli przed konsekwencjami ryzyka pożaru i potrzebę tę odnoszono do wszystkich budynków, nie fetyszyzując tzw. budynków rolniczych, co można zaobserwować obecnie.

Wokół przymusu prawnego ubezpieczenia budynków rolniczych od ognia i innych zdarzeń losowych istnieją bardzo poważne kontrowersje, które ze szczególną wyrazistością pojawiły się podczas prac nad ustawą o działalności ubezpieczeniowej z 1990 r. ${ }^{35}$ Kontrowersje te nasiliły się po wejściu w życie Konstytucji RP z dnia 2 kwietnia 1997 r. ${ }^{36}$, która - opierając się na standardach demokratycznego państwa prawa ${ }^{37}$ - zajęła się również sferą wolności i praw obywatelskich (zob. art. 30-76 Konstytucji RP), łącząc je $z$ konstytucyjną zasadą równości oraz zakazem dyskryminacji ${ }^{38}$.

Wbrew tym konstytucyjnym standardom ${ }^{39}$ ustawa o ubezpieczeniach obowiązkowych nadal utrzymuje przymus ubezpieczenia budynków od ognia i innych zdarzeń losowych, adresując go -

34 Chodzi o dwa dekrety króla Prus z 1803 i 1804 r.; E. Kowalewski, Prawo ubezpieczeń gospodarczych, s. 65.

35 Por. J. Łopuski, E. Kowalewski, O potrzebie przebudowy prawa ubezpieczeń gospodarczych, PiP 1990, nr 1, s. 5-18.

36 Dz.U. Nr 78, poz. 483.

37 Szerzej Prawo konstytucyjne, red. Z. Witkowski, Toruń 2001, s. 102 i n.

38 W orzeczeniu Trybunału Konstytucyjnego z dnia 6 kwietnia 1993 r. (K.7/92, OTK 1993/I poz. 7) stwierdzono m.in.: „zgodnie [...] z utrwalonym w orzecznictwie Trybunału Konstytucyjnego poglądem, zasada równości polega na tym, że wszystkie podmioty prawa charakteryzujące się daną cechą [...] mają być traktowane według jednakowej miary, tj. bez zróżnicowań zarówno dyskryminujących, jak i faworyzujących..." Z kolei w orzeczeniu Trybunału z dnia 29 września 1977 r. (K. 15/97, Prok. I Pr. - dodatek 1997, nr 12, poz. 51) stwierdzono: „[...] odstępstwa od równego traktowania przez prawo sytuacji podobnych są dopuszczalne, ale pod warunkiem spełnienia pewnych przesłanek, a mianowicie relewantności [...] proporcjonalności oraz związku z innymi normami, zasadami lub wartościami konstytucyjnymi, uzasadniającymi odmienne traktowanie podmiotów podobnych [...]". Obydwa orzeczenia podano w pracy, przytoczonej w przyp. 37, s. 586 oraz s. 589.

39 Szerzej B. Gronowska [w:] Prawo konstytucyjne, s. 102-104. 
z trudnych do racjonalnego uzasadnienia powodów - jedynie do ograniczonej grupy posiadaczy budowli, czyli tzw. posiadaczy budynków rolniczych ${ }^{40}$. Dyskryminacyjny charakter tego rozwiązania jest oczywisty, gdyż różnicuje ono w istotny sposób status prawny posiadaczy budynków, ograniczając prawo niektórych z nich do decydowania o swoim mieniu, a w szczególności ogranicza sferę praw właścicielskich, przymuszając ich do ponoszenia istotnych ciężarów finansowych związanych $z$ obowiązkiem zabezpieczenia własnego mienia przed szkodą. Należy dodatkowo podkreślić, że - inaczej niż w przypadku ubezpieczenia OC rolników ${ }^{41}$ - ubezpieczenie budynków rolniczych nie pełni funkcji ochrony osób trzecich, a więc jego przymus nie może być uzasadniony społeczną argumentacją odnoszącą się do interesu ogółu poszkodowanych.

\section{Zastrzeżenia co do obowiązku ubezpieczenia $\mathrm{OC}$ rolników}

Ubezpieczenie OC rolników w formie obowiązkowej zostało w Polsce wprowadzone $z$ początkiem 1976 r. ${ }^{42}$ Przyczyną wprowadzenia tego obowiązku było wyeliminowanie, a co najmniej złagodzenie, niekorzystnego $\mathrm{z}$ punktu widzenia efektywnej gospodarki rolnej obciążenia indywidualnych gospodarstw rolnych finansowymi następstwami szkód wyrządzonych przez rolników osobom trzecim ${ }^{43}$. Choć oczywistym motywem tego rozwiązania była także potrzeba ochrony osób przez rolników poszkodowa-

40 Jest nim budynek wchodzący w skład gospodarstwa rolnego, zdefiniowany w art. 2 pkt 2.

41 Por. na ten temat E. Kowalewski, Ubezpieczenie odpowiedzialności cywilnej. Funkcje i przemiany, Torun 1981, s. 74 i n.

42 Na mocy rozporządzenia Rady Ministrów niemającego wyraźnego umocowania ustawowego (por. Dz.U. z 1976 r. Nr 28, poz. 145).

43 W szczególności chodziło o liczne wówczas przypadki kolizji drogowych powodowanych zaprzęgami konnymi. 
nych ${ }^{44}$ oraz osób wykonujących sezonowe lub sporadycznie określone prace $\mathrm{w}$ gospodarstwach rolnych ${ }^{45}$, to należy sądzić, iż nie były to przyczyny decydujące. Wprowadzenie w obowiązkowej formie ubezpieczenia OC rolników indywidualnych było także podyktowane ówczesnym niedowładem rolnictwa, chroniczną jego niewydolnością i małą produktywnością, ciągłym deficytem produktów rolnych na rynku. Wszystko to tworzyło pokusę ingerencji w obszar gospodarki rolnej przy pomocy metod dyrektywnoadministracyjnych, wyrazem czego były w przeszłości tzw. obowiązkowe dostawy, a po ich zniesieniu (co nastąpiło u progu lat 70. XX stulecia) utrzymywanie m.in. prawnego obowiązku ubezpieczenia OC.

Powoływanie się obecnie na tamte motywy uzasadniające potrzebę obowiązkowego ubezpieczenia OC rolników, kiedy produkcja rolna ma zgoła inny charakter i diametralnie różne są jej uwarunkowania i problemy ekonomiczne, nie wydaje się uzasadnione i ma raczej charakter demagogiczny. Wydaje się, iż w obecnych warunkach społeczno-ekonomicznych brak wystarczającego uzasadnienia dla utrzymania obowiązkowości omawianego ubezpieczenia. Obowiązek taki nie został wprowadzony w większości krajów rozwiniętych gospodarczo, a odniesienie go wyłącznie do rolników indywidualnych ( $\mathrm{z}$ wyłączeniem podmiotów spółdzielczych i innych właścicielskich struktur prawnych ${ }^{46}$ ) rodzić może nawet wątpliwości co do tego, czy nie narusza to w obecnych warunkach konstytucyjnej zasady równości podmiotów wobec prawa.

44 Szerzej E. Kowalewski, op.cit., s. 74.

45 Osoby te nie były w owym czasie - podobnie jak sami rolnicy - objęte powszechnym systemem ubezpieczeń społecznych. Dlatego m.in. obowiązek ubezpieczenia OC rolników był początkowo połączony z obowiązkowym ubezpieczeniem NW.

$46 \mathrm{~W}$ rolnictwie, nawet po likwidacji tzw. PGR-ów, działają stosunkowo liczne gospodarstwa w formie spółdzielni, w tym także spółdzielni zrzeszających kółka rolnicze. 


\section{Regulacja obowiązkowego ubezpieczenia komunikacyjnego OC jako szczególny problem techniczno-legislacyjny}

Potrzeba ustawowego uregulowania obowiązkowego ubezpieczenia OC posiadaczy pojazdów nie może być (i nie jest) kwestionowana. Wątpliwości jednak powstają, jeśli zastanowić się nad techniczno-legislacyjnym usytuowaniem tej regulacji na tle przyszłego kodeksu ubezpieczeń. $Z$ jednej strony wydaje się oczywiste, że cywilnoprawna materia tej umowy (stosunku) powinna podlegać tej samej regulacji co ogół cywilnych stosunków ubezpieczenia, a więc powinna znaleźć swe miejsce w architekturze kodeksu (ogólne prawo o umowie ubezpieczenia plus szczególne regulacje dotyczące umowy ubezpieczenia obowiązkowego). To jednak nie wyczerpuje całości skomplikowanej i niejednorodnej materii wiążącej się $z$ funkcjonowaniem ubezpieczeń obowiązkowych. Trzeba bowiem pamiętać, że obejmuje ona także specyficzne uregulowania organizacyjne $\mathrm{i}$ instytucjonalne, wiążące się np. z UFG, PBUK, reprezentantem do spraw roszczeń czy tzw. organem odszkodowawczym. Do tego należy dodać ważną i specyficzną materię kontroli obowiązku ubezpieczenia oraz sankcji za jego naruszenie. Już prima facie widać, że tej obszernej materii nie uda się zmieścić w regulacjach cywilnoprawnych odnoszących się do ogółu stosunków ubezpieczenia obowiązkowego. Związku z tym wydają się możliwe dwa techniczno-legislacyjne sposoby usytuowania tej materii: albo w kodeksie ubezpieczeń (lecz w odrębnym dziale, rozdziale czy księdze) albo poza tym kodeksem, czyli w odrębnej ustawie o obowiązkowym ubezpieczeniu komunikacyjnym OC. Ponieważ szereg krajów (np. Francja, Niemcy, Austria, W. Brytania) obrało tę drugą drogę, opowiadam się za takim właśnie rozwiązaniem. Taką koncepcję można byłoby obrazowo określić jako koncepcja specustawy. Przyznać jednak należy, że sprawa ta jest wysoce dyskusyjna ${ }^{47}$.

47 Trzeba bowiem mieć na uwadze, że materia obowiązkowego ubezpieczenia komunikacyjnego OC stanowi w istocie przedmiot ujednoliconych regulacji w skali Unii Europejskiej. Oznacza to, że polskie regulacje tak 


\section{$X$. Konsekwencje naruszenia obowiązku ubezpieczenia}

Należy podkreślić, że prawo nasze nie przewiduje jakiejś jednej ani tym bardziej jednolitej sankcji na niezawarcie lub nieposiadanie przez osobę zobowiązaną ubezpieczenia obowiązkowego. Stosowane są różne sankcje, i to o bardzo zróżnicowanym charakterze ${ }^{48}$. Mogą one przybierać następujące formy:

- sankcji finansowej (kara pieniężna nakładana przez UFG, organ administracji lub inny uprawniony podmiot),

- sankcji o charakterze wykroczenia (np. w myśl ustawy o ruchu drogowym, nieposiadanie przez kierującego pojazdem dowodu zawarcia ubezpieczenia OC stanowi wykroczenie),

- specyficznej sankcji administracyjnej (np. nieudzielanie zezwolenia czy koncesji na wykonywanie określonej działalności oraz cofnięcie takiej koncesji czy zezwolenia w stosunku do osób, które nie zawarły bądź nie przedłużyły wymaganego ubezpieczenia),

- sankcji typu korporacyjno-zawodowego (np. niemożność wykonywania zawodu adwokata czy radcy prawnego, włącznie $z$ ewentualną możliwością skreślenia $z$ lisy adwokatów czy radców),

- sankcje typu kontraktowego (np. niemożność przystąpienia do konkursu ofert czy przetargu w przypadku kontraktów wymagających posiadania przez przystępującego do przetargu ubezpieczenia OC),

naprawdę są wierną implementacją dyrektyw unijnych (tzw. dyrektyw komunikacyjnych). Stąd też regulacja ta, także w zakresie warunków tego ubezpieczenia, powinna być jednolita dla całego kraju, a więc o ustalaniu OWU przez poszczególne zakłady nie może być tu mowy. Dotyczy to nie tylko uregulowań organizacyjnych i instytucjonalnych, ale także pewnego obszaru cywilnoprawnego (np. kwestia wymaganych minimalnych sum gwarancyjnych, kwestia tzw. regresu szczególnego, problem braku ubezpieczenia przez zobowiązanego czy określenie trybu dochodzenia roszczeń, zwłaszcza z tzw. wypadków transgranicznych).

48 Szeroko na ten temat - E. Kowalewski, Jeśli nie zawarłeś umowy ubezpieczenia OC, Prawo Europejskie 2003, nr 6-7, s. 69-72. 
- sankcji w drogowym ruchu granicznym albo w żegludze morskiej czy lotniczej (np. niemożność przekroczenia granicy państwowej przez kierującego pojazdem, który nie posiada wymaganego ubezpieczenia OC w ruchu zagranicznym, zakaz żeglugi dla statków przewożących więcej niż 2 tys. ton oleju luzem bez certyfikatu stwierdzającego posiadanie ubezpieczenia OC lub innego równorzędnego zabezpieczenia finansowego (art. 274 k.m.), zakazu wejścia takiego statku do portu polskiego oraz opuszczenia takiego portu (art. 274 i 275 k.m.)),

- sankcji typu regresowego (np. posiadacz pojazdu albo rolnik, którzy nie zawarli wymaganego ubezpieczenia OC i wyrządzili szkodę, mają obowiązek zwrotu UFG odszkodowań i świadczeń, które zostały wypłacone przez ten Fundusz osobie poszkodowanej),

- innej specyficznej restrykcji, niemieszczącej się w wymienionych grupach (np. odmowa wpisu bądź wykreślenie $z$ rejestru polskich statków powietrznych, których właściciel lub użytkownik nie posiada wymaganego ubezpieczenia OC $z$ tytułu użytkowania statku powietrznego (art. 37 ust. 3 pkt 4 prawa lotniczego z 2002 r.).

Na koniec trzeba podkreślić, jako konsekwencję niejako oczywistą, iż sprawca szkody, który nie zawarł umowy ubezpieczenia OC, będzie musiał sam ponieść finansowe ciężary z tego tytułu. Inaczej sytuacja może - na pierwszy rzut oka - wyglądać jedynie w przypadku obowiązkowego ubezpieczenia OC posiadaczy pojazdów oraz OC rolników, kiedy to wobec poszkodowanego przez nieubezpieczonego sprawcę szkody odpowiada UFG (zob. art. 98 ust. 1 pkt 1-2 ustawy o ubezpieczeniach obowiązkowych). Lecz ostatecznie i tak nieubezpieczony sprawca poniesie finansowy ciężar wypłaconych przez UFG odszkodowań, ponieważ Funduszowi temu przysługuje prawo dochodzenia zwrotu wypłaconych odszkodowań od sprawcy i osoby, która nie dopełniła obowiązku zawarcia umowy ubezpieczenia (zob. art. 110 ust. 1 ustawy).

Szczególne miejsce w owym rozległym katalogu sankcji zajmują sankcje typu pieniężnego, czyli tzw. opłaty. W odniesieniu do powszechnych ubezpieczeń obowiązkowych, czyli tych, których 
warunki mają swoją regulację w przepisach ustawy o ubezpieczeniach obowiązkowych ${ }^{49}$, opłaty te uregulowane są ustawowo ${ }^{50}$.

W odniesieniu do niektórych innych rodzajów ubezpieczeń obowiązkowych wysokość owych opłat pieniężnych ustalana jest corocznie (nie bardzo wiadomo, na jakiej podstawie) przez ministra finansów ${ }^{51}$. Natomiast w zakresie innych - bardzo licznych - ubezpieczeń obowiązkowych (np. komorników, przedsiębiorstw turystycznych i pośredników turystycznych, organizatorów imprez masowych, rzeczoznawców majątkowych, pośredników sprzedaży nieruchomości i wielu innych) opłat pieniężnych się nie przewiduje, choć również nie wiadomo dlaczego.

Z powyższych uwag wynika, że problematyka sankcji (zwłaszcza pieniężnych) przewidzianych na wypadek naruszenia prawnego obowiązku ubezpieczenia jest de lege lata uregulowana niebywale niespójnie, by nie rzec niechlujnie. Nawiązując do koncepcji kodeksu ubezpieczeń, trzeba zatem pochylić się i nad tym zagadnieniem. Przede wszystkim nasuwa się pytanie, czy kwestia ustalania tych sankcji (zwłaszcza wysokości opłat pieniężnych) jest w ogóle materią kodeksową. Odpowiedź powinna być jednoznacznie negatywna. Sprawa ta mogłaby znaleźć swoją regulację w poszczególnych ustawach merytorycznych, wprowadzających dany rodzaj ubezpieczenia obowiązkowego ${ }^{52}$.

Zupełnie inaczej jest jednak w odniesieniu do określenia skutków cywilnoprawnych, jakie powstaną (zwłaszcza po stronie osoby poszkodowanej) w sytuacji braku obowiązkowej ochrony ubezpieczeniowej, czyli wówczas, kiedy podmiot zobowiązany nie posiada

49 Chodzi o ubezpieczenie OC posiadaczy pojazdów (art. 23-43), ubezpieczenie OC rolników (art. 44-58) oraz ubezpieczenie budynków rolniczych (art. 59-77).

50 Por. art. 84-95 ust. o ubezpieczeniach obowiązkowych.

51 W formie obwieszczenia, publikowanego w Dzienniku Urzędowym M.F. Por. na ten temat E. Kowalewski, op.cit., s. 70-71.

52 Nadto w przypadkach obowiązkowych ubezpieczeń OC, przewidzianych dla poszczególnych zawodów (zwłaszcza tzw. korporacyjnych), egzekwowanie tego obowiązku i jego sankcjonowanie należałoby pozostawić w gestii poszczególnych korporacji, zrzeszeń czy samorządów - tak J. Łopuski, op.cit., s. 67. 
wymaganego ubezpieczenia. W odniesieniu do ubezpieczeń OC (a tylko takie uznaję za nadające się do form obowiązkowych) należałoby - w imię ochrony poszkodowanych - zaproponować rozwiązanie funkcjonujące obecnie w zakresie ubezpieczenia OC posiadaczy pojazdów i OC rolników (zob. art. 98 ust. 1 ustawy o ubezpieczeniach obowiązkowych), polegające na możliwości dochodzenia roszczeń odszkodowawczych przez poszkodowanych w stosunku do UFG. To $z$ kolei wymagałoby wyposażenia UFG w prawo zwrotnego dochodzenia od nieubezpieczonych sprawców tzw. regresu szczególnego. Powyższe kwestie powinny - bez wątpienia - znaleźć swoje miejsce w kodeksie ubezpieczeń, najlepiej w części szczegółowej regulacji stosunku ubezpieczenia obowiązkowego albo w jego części ustrojowej, poświęconej organizacji i funkcjonowaniu Ubezpieczeniowego Funduszu Gwarancyjnego ${ }^{53}$.

\section{Podsumowanie}

Problematyka ubezpieczeń obowiązkowych to jeden $z$ najważniejszych obszarów regulacyjnych, wymagający w miarę całościowego usytuowania w architekturze przyszłego polskiego kodeksu ubezpieczeń. Tym samym utrzymywanie dotychczasowego dualizmu regulacyjnego umowy ubezpieczenia dobrowolnego (w k.c. i k.m.) oraz obowiązkowego (w przepisach ustawy o ubezpieczeniach obowiązkowych) straciłoby rację bytu w imię ostatecznej petryfikacji jednolitości prawnego stosunku ubezpieczenia. Zadanie wkomponowania materii ubezpieczeń obowiązkowych w ramy kodeksu wymagać będzie jednak rozstrzygnięć, co do wielu kwestii merytorycznych oraz techniczno-legislacyjnych, które nazwałem dylematami prawa ubezpieczeń obowiązkowych.

Jednym $z$ nich jest nowa definicja, a raczej redefinicja pojęcia ubezpieczenia obowiązkowego, wraz $\mathrm{z}$ określeniem kryteriów warunkujących wprowadzenie w danej dziedzinie stosunków takiego obowiązku. $Z$ tym z kolei łączy się oczywista potrzeba ograniczenia

53 Jak to jest obecnie - rozdz. 7 ustawy o ubezpieczeniach obowiązkowych (art. 96-119). 
liczby tych ubezpieczeń, a od strony rodzajowej (przedmiotowej) ograniczenia ich jedynie do ryzyka odpowiedzialności cywilnej, poza które katalog ubezpieczeń obowiązkowych nie powinien wykraczać, co ma miejsce de lege lata.

W artykule poruszono też kwestie techniczno-legislacyjnego usytuowania regulacji ubezpieczeń obowiązkowych $\mathrm{w}$ architekturze kodeksu. Szczególną trudność przedstawia w tym kontekście materia ubezpieczeń komunikacyjnych OC, która mogłaby zostać objęta zakresem odrębnej ustawy, tak jak to jest w innych ustawodawstwach, włącznie $z$ tymi, które mają już kodeks ubezpieczeń (np. Francja).

\section{SUMMARY}

\section{Dillemas of obligatory insurance and the Insurance Code}

This article presents the main issues and dilemmas concerning the obligatory insurance and its regulation in the future Insurance Code. Author examines the sole concept of this kind of insurance and emphasizes the need of redefining it. Apart from stressing the need of implementing the new Insurance Code, Author makes fundamental remarks as to the obligatory insurance as a part of the new Code. It is stressed that the content of this insurance should be precise and the new Code should provide for a catalogue of types of obligatory insurance. Mainly, the Code should define the scope and subject of the obligatory insurance. The Article contains several proposals for legislative solutions in this matter.

Keywords: insurance law, Insurance Code, obligatory insurance 